\title{
A DEBRECENI EGYETEM ELEKTROMOS MEGHAJTÁSÚ VIRÁGKOCSIJÁNAK TERVEZÉSE ÉS MEGVALÓSÍTÁSA
}

\section{PLANNING AND BUILDING THE ELECTRIC FLOWER CARNIVAL CAR OF THE UNIVERSITY OF DEBRECEN}

\author{
Apagyi Antal ${ }^{1}$, Szmolka Tamás ${ }^{2}$, Husi Géza ${ }^{3}$ \\ Debreceni Egyetem, Müszaki Kar, Debrecen, Magyarország \\ ${ }^{1}$ apagyi.toni@gmail.com \\ ${ }^{2}$ szmolka.tomi012@gmail.com \\ ${ }^{3}$ husigeza@eng.unideb.hu
}

\begin{abstract}
In this research we will discuss the creation of the flower cart. It will be viewed from an economical and enviromental perspective also it is safe to say that the planning process of the carrying capacity and the battery runtime is well explained in the article. The cart is moved by three-phase electric motors and the motors are controlled by Variable Frequency Drives (VFD). The power to the electric parts comes from the large battery pack. Overall the purpose of this vehicle is to be able to participate in the march increasing the quality of the event.
\end{abstract}

Keywords: VFD, electric, inverter, flower-carnival-car.

\section{Összefoglalás}

Ezen kutatásunk során a Debreceni Egyetem elektromos működésű virágkocsijának a megépülését, annak a gazdaságosságát, környezetre gyakorolt hatását vizsgáljuk. A munka során foglalkoztunk méretezési kérdésekkel, melyek a teherbírást és a hatótávot helyezték a figyelem középpontjába. Az autó mozgását háromfázisú aszinkronmotorokkal biztosítjuk, melyeket frekvenciaváltók segítségével vezérlünk. Az energiaellátást akkumulátorok szolgáltatják a villanymotoroknak. A kocsi feladata a virágkarneválon történő felvonulás és a karnevál színvonalának emelése.

Kulcsszavak: frekvenciaváltó, elektromos, akkumulátor, virágkocsi, virágkarnevál.

\section{Bevezető}

A debreceni virágkarnevált 1966 óta rendezik meg, minden év augusztus 20-án Debrecenben [1]. Magyarország egyik legismertebb rendezvénye, amely államalapító Szent István király szentté avatásához, államalapítás és az új kenyér ünnepéhez kötődik. Évtizedek óta meghatározó ünnepély a város életében, kezdetben csak egy napos rendezvény volt, napjainkban már egy karneváli hét előzi meg a 20-i ünnepséget. Minden évben cél a közönség elkápráztatása szebbnél szebb virágkocsikkal, a felvonulók lenyűgöző táncos, zenés műsoraival. Fontos, hogy évről évre mutasson a város valami új dolgot, amivel még több látogatót vonzhat a városba. Egy ilyen újdonság volt a Debreceni Egyetem elektromos meghajtású virágkocsija is, ami egyedülálló a többi kocsival szemben. Korszerü és modern. Néhány esetben a felvonulás élményét maguk a virágkocsik csökkentik ugyanis belsőégésű motorral rendelkeznek. Ezek a járművek nem korszerű konstrukciók, több mint 30 évesek, zajosak, kellemetlen szagú a kipufogógázuk. A kocsik mögött például táncos, olasz zászlóforgató csoportok vonulnak. Annak érdekében, 
hogy a felvonulók egyik legszebb és legfontosabb napját ne árnyékolja be a büdös kipufogógáz így innovációra volt szükség. A Debreceni Egyetem már több mint 10 éve indít saját kompozícióval virágkocsit, azonban 2016 augusztusára az egyetem elkészítette a saját, egyedi virágkocsiját [2]. Ennek a különlegessége a teljesen elektromos hajtásban rejlik. A megvalósított új kocsit nagy örömmel fogadta Debrecen város, a fellépők és a közönség is. Mivel a kocsi teljes mértékben az egyetem tulajdona, így a felmerülő karbantartási munkálatokat továbbra is teljes mértékben az egyetem hallgatói és oktatói közösen végzik. A Műszaki karon néhány főből álló csapat végzi ezeket a munkálatokat. Alsóbb éves hallgatóknak adjuk át a tudást, tapasztalatot, ők szakmai ismeretek szerzése mellett, felejthetetlen élményekkel gazdagodnak valamint öregbítik egyetemünk hírnevét. Egy ilyen csapatban dolgozni megtisztelő érzés.

\section{Előzmények}

\subsection{A hagyományos és az elektromos meg- hajtás összehasonlítása}

Az elektromos meghajtású járművek egyre nagyobb térhódításának egyik fő oka a belsőégésű motorok kedvezőtlen hatásfokából és környezetszennyező hatásából ered. A légszennyezés napjainkban elég súlyos problémának számít, ennek okozói legnagyobb részt az erőművek, gyárak és járművek. Az általuk kibocsátott gázok súlyos légszennyező és ózonréteg károsító hatása évtizedek óta ösztönzi az emberiséget újabbnál újabb technológiai megoldások kifejlesztésére az ipar minden területén.

A 1. ábrán a diagram jól szemlélteti évek szerinti lebontásban a dízelmotorok hatásfokának, valamint az üzemanyag gazdaságosság fejlődését.

Kutatásaink alapján a dízelmotorok hatásfoka napjainkban 30-38 \% [3] körülire tehető, amely összehasonlítva a villanymotorok 80-90 \% hatásfokával, igencsak kedvezőtlen. Előbbi esetében hő és számos további veszteség formájában távozik a rendszerből teljesítmény, amely ezt a kedvezőtlen hatásfokot adja.

Környezetvédelmi szempontból a lokális károsanyag kibocsátó hatása egy elektromos hajtású járműnek gyakorlatilag nullának tekinthető. A légszennyezés nem a városban jelenik meg, hanem a peremterületeken az erőművekben, ahol az alkatrészek, akkumulátorok gyártása, elektromos áram előállítása történik. Összességében véve a gyártás során felszabaduló $\mathrm{CO}_{2}$ gáz meny-

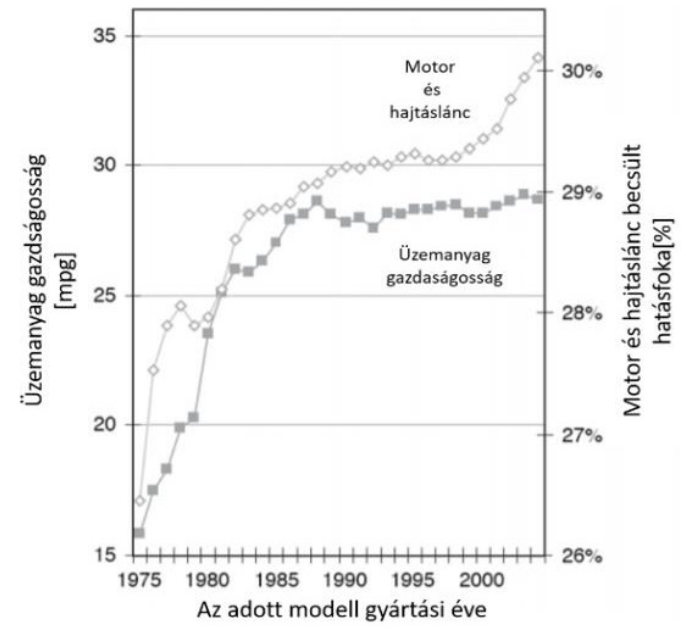

1. ábra. Üzemanyag gazdaságosság [3]

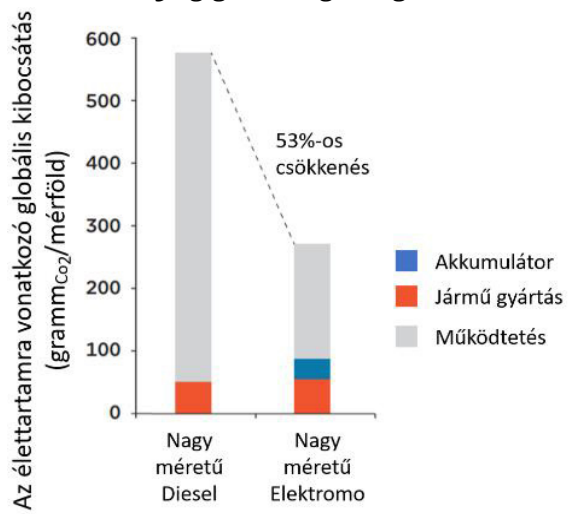

2. ábra. Az élettartamra vonatkozó globális

nyisége nagyobb, mint hagyományos hajtású járművek esetében, viszont élettartamra vetítve jóval kedvezőbb értéket kapunk egy elektromos autó esetében.

A széndioxid lábnyom kibocsátás tovább csökkenthető, ha például nap vagy szélenergiából állítjuk elő a szükséges “üzemanyagot”. Nagy előnye az elektromos meghajtású járműveknek az is, hogy fékezéskor a motor generátor üzembe kapcsol és visszatáplál az akkumulátorra kibocsátás. [4]

\subsection{A tervezés}

Az egyetem számára az innováció mindig is meghatározó érték volt, amelyet tökéletesen reflektál egy ilyen jellegű fejlesztés kivitelezése. A Debreceni Egyetem Műszaki Kar Mechatronika mérnöki Tanszék oktatói és hallgatói által közösen készített tervek 2016-ra érték el megvalósítható formájukat. Ennek a során a fő szempontok, a lokális károsanyag kibocsátás nullára történő csökkentése, a hagyományos kormányzás újszerü 
megoldása volt. A tervezés során figyelembe kellett venni, a virágkarneváli vonulás útvonalának adottságait, mint például a villamos megállók közötti távolságot a szélesség megtervezésekor, csak úgy, mint a maximális magasság tervezését, amelyet a nagyfeszültségű felsővezetékek határoznak meg. Utóbbira azért volt szükség, mert a kocsik az indulási helyszínre egy raktárból kezdik meg útjukat, ami trolibusz útvonalakat keresztez.

\section{Az elektromos virágkocsi felépítése}

A hajtás egésze egy kiválasztott alváz köré épül fel. Így a felhasznált alváz méreteinek helyes megválasztása az új hajtás tervezéséhez elengedhetetlen. Az elérhető alvázak főleg belső égésű teherautókból származnak. A virágkocsinál tehát, ahhoz, hogy teljesen elektromos működésűvé váljon számos módosítás elvégzésére volt szükség.

\subsection{Az alváz}

Először is egy alváz kiválasztása volt szükséges. A tervezők választása egy teherautó alvázra esett, amely kellő teherbírással és mérettel rendelkezik ahhoz, hogy a 4x8 m méretű felépítményt ráhelyezzenek. A keretnél figyelembe kell venni továbbá a hungarocell szobrok vas vázának, a több ezer élővirágnak, gyeptéglának a tömegét is. Ahhoz, hogy stabilan állhassanak a szobrok, a keretre felülről egy erősített deszkázat került.

Esetünkben a hagyományos tehergépjármü elemekre, mint például dízelmotor, kompreszszor, hidraulika szivattyú, üzemanyagtartály, kormánykerék nem volt szükség a továbbiakban, így eltávolításra kerültek.

\subsection{Hajtás és kormányzás}

Ahhoz, hogy a jármű újra működőképes legyen, az eltávolított elemek pótlására új eszközök kerültek beszerelésre. A kormányzásért, kormánykerék helyett aszinkronmotor és a dízelmotor helyett szintén villanymotor teljesít szolgálatot.

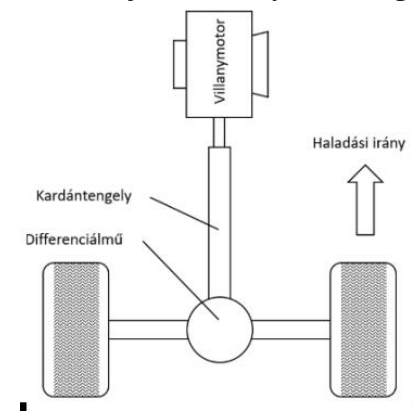

3. ábra. A virágkocsi meghajtása
A hajtásért felelős 18 kW teljesítményű aszinkronmotor az eredeti sebességváltón és kardántengelyen keresztül hajtja meg a differenciálművet, ezáltal biztosítva a kocsi haladását. A kormányzásért a kisebbik, $5 \mathrm{~kW}$ teljesítményű elektromotor a felelős. A működési elv a 4. ábrán [5] látható.

A villanymotor a globoidcsigás kormánygépen található pittman kar segítségével tolóerőt fejt ki a kormányrúdra, amely a tengelycsonkon elhelyezkedő kerekek elfordulását eredményezi. A pittman kar véghelyzeteinél egy-egy végálláskapcsoló helyezkedik el, amik megszüntetik a villanymotor hajtását, így elkerülve a kormányzás mechanizmusának károsodását.

\subsection{Vezérlés}

A motorok vezérlését inverterek, másnéven frekvenciaváltók alkalmazásával valósítjuk meg. Mivel háromfázisú aszinkron villanymotorokat használunk, így szükséges az akkumulátor egyenáramát váltakozóárammá átalakítani. A frekvenciaváltónak szolgáltatott megfelelő vezérlő jellel vezéreljük a villanymotorokat. Az analóg vezérlő jeleket “joystick”-ok, azaz potenciométerek mozgatásával kapjuk meg. A frekvenciaváltó eszerint a jel szerint, ami 0-10 V között változik a potenciométer állástól függően, megfelelteti a beállított frekvenciatartományt, ami jelenleg 0-50 Hz-ig terjed, tehát a 0V 0Hz-nek, míg $10 \mathrm{~V}$ $50 \mathrm{~Hz}-n e k$ felel meg, ezáltal növeljük vagy csökkentjük a kocsi sebességét. A kormányzás is hasonló elven működik annyi különbséggel, hogy itt a különböző előjelű vezérlőjel minden esetben a beállított, maximális frekvenciával forgatja a kerekeket valamelyik irányba. A kormányzásért felelős joystick esetében tehát nem jelent semmit a kitérítés mértéke, csak az iránya.

\subsection{Energia visszatáplálás}

A virágkocsi fékezéséről is gondoskodni kell, ez szintén a frekvenciaváltó nyújtotta lehetőségeknek köszönhetően egyszerűen megvalósítható. Az

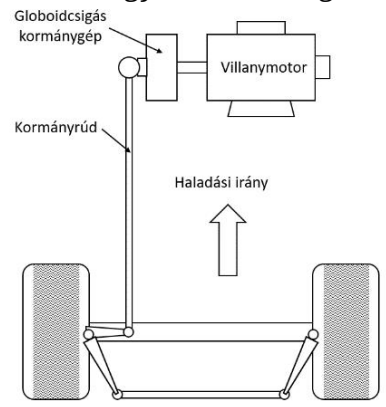

4. ábra. Merevhidas futómü kormánymechanizmusa 
indukciós motor esetében egyszerűen létrehozható a regenerálás. Ennek oka a motor működési elvéből következik. Ha megfelelő mechanikai nyomatékot hozunk létre a motor tengelyén, valamint a motor kapcsaira elektromos terhelést kötünk, akkor a Lorentz erő miatt a motor bordáiban áram indukálódik. Szerencsénkre a frekvenciaváltó rendelkezik beépített regeneratív fékezési funkcióval, így külső áramkör építése nélkül tudunk dolgozni. Ehhez a fékezési módhoz szükség van úgymond fékező ellenállásokra, ahol fékezés következtében létrejövő energia eldisszipálódik. A sok fékezés következtében probléma lépett fel a fékező ellenállás hűtésekor. Ennek a kiküszöböléseként az akkumulátort használjuk „fékező ellenállásként”, így fékezéskor közvetlenül töltődik az akkumulátor. A regenerálás hatásfoka viszonylag magas, a kerék és a motor közötti direkt kapcsolatnak köszönhetően ez 85-95\%. A joystick karok rugóvisszatérítéssel rendelkeznek, így azok elengedése után középállásba térnek vissza, ezáltal bekapcsol a fékező üzemmód így kocsi lelassul, majd megáll. Üzemen kívüli rögzítéshez, a teherautón eredetileg is megtalálható mechanikus fékek működtetésére van szükség.

\subsection{Az áramforrás}

A virágkocsiban a tápfeszültséget az egymással sorosan és párhuzamosan kapcsolt akkumulátor cellák biztosítják. A kocsi 2 eltérő feszültségű áramkört tartalmaz. A nagyfeszültségü kör 160 cellát foglal magába melyeknek a sorosan megvalósított összekapcsolása 640 V feszültséget szolgáltat. A kisfeszültségü kör 12 V feszültség értéket ad, itt 6 cella van sorosan és párhuzamosan kapcsolva úgy, hogy a feszültsége $12 \mathrm{~V}$ legyen. Ez szolgáltatja a tápfeszültséget a mágneskapcsolók számára, amelyek a nagyfeszültségü áramkört kapcsolják, hogy a kocsi áramtalanítása megtörténjen. A sofőr számára komfortérzet növelése érdekében egy mérőóra is került beszerelésre a vezetőfülkébe, így menet közben továbbá töltéskor is ellenőrizhető az akkumulátorok töltöttségi szintje. Mérőórák beszerelésére 2018 nyarának a folyamán került sor. Az említett órák töltöttségi feszültség szintet és töltési áramot képesek mérni. A feszültségmérő méréshatárának a kibővítésére előtét ellenállást alkalmaztunk. Ennek a fontossága amiatt jelentkezett, mert az akkumulátorpakk összegzett maximális feszültsége $640 \mathrm{~V}$ míg a műszeré mindössze $300 \mathrm{~V}$. A mérőóra méréshatára 10 A így annak a módosítására szükség nem volt. Mivel 640 V-ról van szó így kellő körültekintés és tervezés előzte meg a beépítést.

\section{Fejlesztési lehetőségek}

Az eddigi évek bizonyítják, hogy teljesen megbízható és biztonságos a kifejlesztett elektromos hajtású jármű. A fejlesztési tervek szerint a cellák töltöttségi szintjét akkumulátor felügyeleti rendszerrel kiegészítve lehetne szabályozni, amely egy teljesen automatizált rendszer. Ezzel kiküszöbölhető, a cellák jelenleg éves kötelező ellenőrzése. Jelenleg az autón vezeték nélküli távirányíthatósága is a fejlesztés alatt van. Erre a feladatra való előkészítés komoly tervezést és szakértelmet igényel. Ezáltal a kocsin található kompozíciók élvezhetősége is tovább nő, mivel nincs szükség arra, hogy a jármű vezetője bent üljön a sofőrfülkében. Ahhoz, hogy a távirányítás augusztus 20-án élesben is bemutatkozzon a közönség előtt, a lehető legbiztonságosabbá kell tenni a járművet, például ultrahangos szenzorokkal szükséges felszerelni, többkörös fékrendszert kell alkalmazni. Előbbi megoldás fejlesztése jelenleg is zajlik, ugyanis komoly problémát jelent a kompozíciót alkotó növények leveleinek a belógása az érzékelési tartományba, emiatt nagyon sok hamis riasztást és vészfékezést produkál a virágkocsi. Továbbá a kompozíciók látványa mellé hanghatások is társulnak, ezek elindítása, megállítása, hangosítása, halkítása mind távirányítóról kell, hogy vezérelhető legyen. Ahhoz, hogy a hangzás ténylegesen élményt nyújtson fontos, hogy a közönség számára hallhatónak kell lennie, azaz olyan megoldást kell keresni, ami a hungarocell borításon keresztül is jól élvezhető.

\section{Szakirodalmi hivatkozások}

[1] Debreceni virágkarnevál. Történet. (2017. 08 10.). http://debreceniviragkarneval.hu/tortenet/

[2] Dehir: Kétezer akkumulátor hajtja majd az egyetem virágkocsiját - videóval. (2016)

http://www.dehir.hu/debrecen/ketezer-akkumulator-hajtja-majd-az-egyetem-viragkocsijat/2016/07/18/

[3] Nemet G.: Automobile Fuel Efficiency Standards. Historical Case Studies of Energy Technology Innovation In: The global energy assessment. (Eds. Grubler A., Aguayo F., Gallagher K. S., Hekkert M., Jiang K., Mytelka L., Neij L., Nemet G., C. Wilson) Cambridge University Press, Cambridge, UK.

[4] Nealer R., Reichmuth D., Anair D.: Cleaner Cars from Cradle to Grave. Union of Concerned Scientists, 2015, 13.

[5] Kádár L., Varga,F., Kőfalusi P.: Kormányrendszerek jellemző szerkezeti egységeinek elemzése. (2014.)

[6] Bartha I., Vitéz A. Cs., Husi G.: Standard industrial inverter controlled drive chain for various type of EV. (2014). http://hdl.handle.net/2437/228136 